De Jure: Jurnal Hukum dan Syari'ah

Vol. 11, No. 1, 2019, h. 48-62

ISSN (Print): 2085-1618, ISSN (Online): 2528-1658

DOI: http://dx.doi.org/10.18860/j-fsh.v11i1.6574

Available online at http://ejournal.uin-malang.ac.id/index.php/syariah

\title{
Kepemimpinan dan Nafkah Keluarga dalam Perspektif Nalar Tekstualis Ibn Hazm Al-Dzahiriy
}

\author{
Nor Salam \\ Sekolah Tinggi Agama Islam Al-Yasini Pasuruan, Indonesia \\ salamsalembu@gmail.com
}

\begin{abstract}
Abstrak
This study is motivated by the emergence of an assessment of the Dzahiriyah Islamic jurisprudence product, which on the one hand places the textual Dzahiriyah jurisprudence into the category of static jurisprudence, while on the different side it clearly shows the progress of the Dzahiriyah jurisprudence product. Through a study of the book of al-Muhalla written by Ibn Hazm, one conclusion is obtained that the Dzahiriyah madrasah fiqh products have relevance to efforts to build male and female relations in partnership family law and not superior-inferior positions. This can be seen from Ibn Hazm's view of leadership and conditional living in the family. Men and women alike have the possibility of becoming providers and leaders.
\end{abstract}

Kajian ini dilatarbelakangi oleh munculnya penilaian terhadap produk fiqih madzhab Dzahiriyah, yang di satu sisi menempatkan pola pikir tekstualis fiqih Dzahiriyah ke dalam kategori pemikiran fiqih yang statis, sementara pada sisi yang berbeda justru secara jelas menunjukkan progresifitas produk fiqih Dzahiriyah. Melalui kajian terhadap kitab al-Muhalla yang ditulis oleh Ibn Hazm, diperoleh satu kesimpulan bahwa produk fiqh madzhab Dzahiriyah memiliki relevansi terhadap upaya membangun hubungan laki-laki dan perempuan dalam hukum keluarga yang bersifat kemitraan dan bukan posisi superior-inferior. Hal ini dapat dilihat dari pandangan Ibn Hazm tentang kepemimpinan dan nafkah dalam keluarga yang bersifat kondisional. Laki-laki dan perempuan sama-sama memiliki kemungkinan menjadi pemberi nafkah dan pemimpin.

Kata Kunci: nafkah; kepemimpinan; Ibn Hazm al-Dzahiriy

\section{Latar Belakang}

Madzhab Dzahiriyah yang digagas oleh Abu Dawud al-Dzahiri dan ditumbuhkembangkan oleh Ibn Hazm al-Dzahiri tercatat sebagai salah satu aliran dalam fiqh Islam (baca: madzhab) di samping madzhab besar lainnya seperti Madzhab Abu Tsaur, Madzhab Jarir Ibn Thabari dan lain-lain, yang kemudian sejak sekitar tahun 700 $\mathrm{H}$ hanya bertahan empat madzhab dominan yaitu Madzhab Imam Malik, Imam Abu Hanifah, Imam Syafi'i dan Imam Ahmad Ibn Hanbal. ${ }^{1}$ Lahirnya madzhab-madzhab

\footnotetext{
${ }^{1}$ Diana Zacharias, "Fundamentals of the Sunnī Schools of Law," Heidelberg Journal of International Law 66 (2006): 507.
} 
tersebut dicatat pula sebagai "buah manis" dari kebebasan intelektual yang lazim dinyatakan sebagai masa keemasan fiqh Islam, walaupun penting pula dicatat, adanya beragam pendapat para mujtahid "siap saji" yang notabene berasal dari pergulatan intelektual telah menjadi preseden kelesuan intelektual bagi generasi setelahnya.

Banyak sisi menarik yang sejatinya dapat dipotret terkait dengan beragam madzhab fiqh baik yang masih langgeng hingga kini maupun madzhab fiqh yang telah punah. Fiqh Dzahiriyah termasuk madzhab fiqh "pinggiran" di luar madzhab empat yang mendominasi jagat perbincangan ilmu fiqh seperti madzhab Maliki, Hanafi, Syafi'i dan Hanbali. Terhadap madzhab Dzahiriyah ini, label tekstualis ${ }^{2}$ dilekatkan karena dilihat dari model istinbath al-ahkamnya, golongan ini berpegang teguh pada makna dzahir nash al-Quran dan hadis serta ijma' dan menolak penggunaan qiyas karena dinilai sebagai proses perumusan hukum yang lebih mengedepankan akal dari pada nash. ${ }^{3}$ Dengan kata lain, nalar tektualis yang dilekatkan kepada madzhab Dzahiriyah dicirikan dengan kepatuhan terhadap doktrin dzahir, yakni adanya anggapan bahwa wahyu hanya dapat dipahami secara harfiyah tanpa campur tangan logika manusia (baca: qiyas) yang pada akhirnya dinilai hanya dapat mengintervensi maksudmaksud Tuhan. ${ }^{4}$ Atas penolakan madzhab Dzahiriyah terhadap penggunaan qiyas sebagai wujud dari peranan dominan rasio dalam memahami "titah" Tuhan, maka dinyatakan bahwa konsep-konsep yang ditawarkan oleh Ibn Hazm sebagai representasi madzhab Dzahiriyah akan sangat sulit diterapkan sebab dalam pandangan ahli Fiqh Andalusia itu, al-Quran telah final, dan karenanya penggunaan $r a$ 'yu untuk menggali kandungan hukumnya menjadi terlarang secara secara mutlak. Hal ini tentu sarat dengan tindakan memustahilkan perubahan dan perkembangan yang secara cepat terjadi di tengah-tengah masyarakat, yang sejatinya menghendaki terobosan-terobosan hukum yang kompatibel dengan perkembangan yang dimaksudkan. ${ }^{5}$

Di sisi yang berbeda, pola pikir tekstualis yang dikembangkan madzhab Dzahiriyah justru dinilai memiliki relevansi tersendiri dengan perkembangan fakta-fakta hukum yang membutuhkan jawaban dari sisi hukum Islam. Bahkan, terobosan hukum yang digaungkan oleh madzhab ini dinilai lebih liberal dibandingkan dengan pendapat para ahli fiqh di luar madzhab Dzahiriyah. Katakan saja, pemikiran Ibn Hazm tentang kewajiban lain yang bersifat periodik dan temporal berupa jaminan sosial dari orang yang mampu kepada orang yang miskin di samping adanya kewajiban zakat. Pandangan demikian berbeda dengan jumhur ulama yang tidak mewajibkan adanya jaminan sosial. ${ }^{6}$

\footnotetext{
2 Terdapat beberapa istilah yang populer sebagai nama lain dari tekstualisme. Istilah tersebut di antaranya adalah lughawi, ushuli, athari, dzahiri, lafdzi, haqiqi, harfi, literalisme, dan skripturalisme. Ahmad 'Ubaydi Hasbillah, "Nalar Tekstual Ahli Hadis dalam Ormas Modernis dan Tradisionalis Islamdi Indonesia”, Disertasi (Jakarta: UIN Syarif Hidayatullah, 2017), 17.

3 A. Halil Thahir, "Metode Ijtihad Menurut Ibnu Hazm: Telaah Kitab al-Ihkām Fi Ușūl al-Ahkām," Realita: Jurnal Penelitian Dan Kebudayaan Islam 14, no. 2 (2016): 152, https://doi.org/10.30762/realita.v14i2.241; Asmawi, Fiqh Zahiriyah: Metode Penggalian Hukum Islam Dalam Perspektif Historis Sosiologis, 1st ed. (Tulungagung: STAIN Tulungagung Press, 2011), 67.

${ }^{4}$ Maribel Fierro, "Why Ibn Hazm Became a Zāhirī: Charisma, Law and the Court" Hamsa: Journal of Judaic and Islamic Studies 4 (2017-March 2018), 1-21.

5 Hardi Putra Wirman, "Problematika Pendekatan Analogi (Qiyas) Dalam Penetapan Hukum Islam (Telaah atas Pemikiran Ibn Hazm dan Ibn Qayyim al-Jawziyah)," Asy-Syir'ah: Jurnal Ilmu Syari'ah dan Hukum 47, no. 1 (2013): 45, https://doi.org/10.14421/asy-syir'ah.2013.\%x.

${ }^{6}$ Atik Wartini, "Jaminan Sosial Dalam Pandangan Ibnu Hazm Dan Relevansinya Dengan Pengembangan Jaminan Sosial Di Indonesia," HUNAFA: Jurnal Studia Islamika 11, no. 2 (2014): 271, https://doi.org/10.24239/jsi.v11i2.356.245-275.
} 
Dalam kedua penilaian ini, kajian penulis terhadap pemikiran madzhab Dzahiriyah cenderung mengarah pada ketidaksetujuan bahwa pola pikir tekstualis madzhab Dzahiriyah tidak bisa bersanding dengan persoalan-persoalan kekinian. Dalam kajian ini, dengan menjadikan konsep nafkah dan persoalan kepemimpinan dalam rumah tangga, penulis mencoba menelusuri kajian tersebut dalam karya monumental yang ada dalam madzhab Dzahiriyah, yaitu al-Muhalla yang ditulis oleh Ibn Hazm. Secara sistematis-metodologis, kajian yang berbentuk studi literatur ini diawali dengan penelusuran terhadap genealogi madzhab Dzahiriyah dan eksistensinya dalam belantara kajian tarikh tasyri' al-Islami. Kemudian dilanjutkan dengan memaparkan piranti istinbath al-ahkamnya yang dinilai memiliki andil dalam merumuskan produk-produk fiqihnya termasuk dalam hal ini adalah persoalan nafkah dan kepemimpinan dalam rumah tangga. pembahasan selanjutnya adalah pemaparan tentang pemikiran madzhab Dzahiriyah tentang persoalan yang menjadi tema besar dalam kajian ini, yaitu nafkah dan kepemimpinan dalam rumah tangga.

\section{Genealogi Madzhab Dzahiriyah}

Madzhab al-Dzahiri sebagai aliran dalam pemikiran hukum Islam yang berpegang teguh pada keyakinan bahwa sumber hukum Islam adalah nash bukan qiyas, istihsan, maupun maslahah mursalah digawangi oleh dua ulama besar yaitu Dawud al-Isbahani ${ }^{7}$ dan Ibnu Hazm. ${ }^{8}$ Nama yang disebut pertama disebut oleh Abu Zahrah sebagai penggagas madzhab Dzahiriyah karena beliaulah orang yang pertama kali membincang pemikiran tersebut, sementara nama kedua yang disebutkan di atas disebutnya sebagai pelanjut pemikiran Abu Dawud al-Dzahiri. Namun begitu -lanjut Abu Zahrah -Ibn Hazmlah ulama yang begitu kukuh dalam berpegang terhadap aliran Dzahiriyah ini. ${ }^{9}$

Di samping kritik yang diajukan kepada madzhab Dzahiriyah ini, antara lain disebabkan oleh penolakan secara mutlak Abu Dawud al-Dzahiri sebagai pendiri madzhab ini terhadap taklid bahkan bagi orang awam sekalipun, namun pada kenyataannya madzhab al-Dzahiri mengalami perkembangan yang sangat pesat terutama pada abad ketiga dan keempat Hijriyah. Bahkan pada abad-abad tersebut, madzhab al-Dzahiri ditempatkan sebagai madzhab keempat bersanding dengan

\footnotetext{
${ }^{7}$ Nama lengkap Abu Dawud al-Dzahiri adalah Abu Sulaiman ibn Ali ibn Khalaf al-Kufi al-Baghdadi alIsbahani. Beliau popular dengan panggilan Abu Dawud al-Dzahiri. Dilahirkan pada tahun 204 Hijriyah di Kufah, tempat berkembangnya aliran fiqh rasionalis seperti madzhab Abu Hanifah dan lain-lain. Karir keilmuan Abu Dawud dimulai dengan menjadi murid dari seorang muhaddits yang bernama Sulaiman Ibn Harb al-Hafidz. Kemudian dilanjutkan dengan belajar kepada Abdullah Ibn Maslamah al-Qa'nabi -pakar hadis dan fiqih yang juga menjadi salah seorang guru dari Imam al-Bukhari dan Imam Muslim -, dan Musaddad Ibn Masrhad al-Bashri. Tidak puas dengan keilmuan yang telah diperolehnya, Abu Dawud berkelana ke Baghdad dan berguru kepada Abu Tsaur Ibrahim Ibn Khalid Ibn Abu al-Yaman al-Kalabi alBaghdadi -seorang ulama yang digelari dengan ahadu aimmat al-dunya fiqhan wa 'ilman, wara'an wa fadlan. Nuruddin 'Itr, Dawud Al-Asbahani Wa Haqiqat al-Madzhab al-Dzahiri (Nasyim al-Syam, n.d.), $2-3$.

${ }^{8}$ Ibn Hazm memiliki nama lengkap Ali ibn said Ibn Hazm Ibn Ghalib Ibn Shaleh Ibn Khalaf Ibn Ma'dan Ibn Sufyan Ibn Yazid. Beliau populer dengan sebutan Ibn Hazm yang tidak jarang digabung dengan sebutan al-Qurthubi atau al-Andalusi di belakang namanya. Sebutan lain yang tidak jarang dilekatkan kepada Ibn Hazm adalah al-Dzahiri yang menunjuk pada aliran pemikiran fiqh yang dianutnya. Informasi lebih detail seputar biografi dan pemikiran Ibn Hazm dapat dibaca, antara lain; Yaqut al-Hamawy, Mu'jam al- 'Udaba' (Kairo: Dar al-Ma'mun, n.d.), 235-36; Abdul Halim 'Uweis, Ibn Hazm Al-Andalusia Wa Juhuduh Fi al-Bahth al-Tarikhiy Wa al-Hadariy (Kairo: Al-Zahra li al-I'lam al-Arabi, 1988), 89.

${ }^{9}$ Muhammad Abu Zahrah, Tarikh Al-Madzahib al-Islamiyah Fi al-Siyasah Wa al-Aqa'id Wa Tarikh alMadzahib al-Fiqhiyyah (Kairo: Dar al-Fikr al-Arabi, n.d.), 506.
} 
madzhab Syafi'i, Hanafi dan Maliki. Dengan demikian, madzhab al-Dzahiri mengungguli popularitas madzhab yang didirikan oleh Ahmad ibn Hanbal yang disebutsebut sebagai imam al-Sunnah. Kemudian pada abad kelima Hijriyah, Qadli Abu Ya'la menempatkan madzhab Ahmad sebagai madzhab keempat dan secara tidak langsung menggeser popularitas madzhab al-Dzahiriyah. ${ }^{10}$

Perkembangan madzhab Dzahiriyah tidak terlepas dari dua sebab, pertama, disebabkan oleh karya-karya yang ditulis oleh Abu Dawud al-Dzahiri secara keseluruhan memuat hadis dan atsar yang dijadikan sebagai sandaran pemikirannya dalam merumuskan hukum-hukum fiqih. Selain itu, seluruh nash yang dikandungnya menjadi jawaban atas setiap peristiwa yang dibutuhkan oleh setiap muslim dalam kehidupannya. Adapun sebab kedua, erat kaitannya dengan penyebaran pemikiran Abu Dawud oleh generasi berikutnya, termasuk dalam hal ini adalah penyebaran karya-karya Abu Dawud yang dilakukan oleh putranya yang bernama Abu Bakar Muhammad ibn Dawud. ${ }^{11}$ Selain Abu Bakar Muhammad Ibn Dawud, tercatat beberapa nama yang dinilai sebagai pelanjut terhadap madzhab Dzahiriyah. Mereka antara lain adalah Ahmad Ibn Muhammad al-Qadli al-Manshuri, Abdullah Ibn Ali Ibn Husain Ibn Muhammad al-Nakha'i al-Dawudi, Abdul Aziz Ahmad al-Jazri al-Asfahani, Ali Ibn Hazm al-Dzahiri dan Ibn al-Hilal yang dijuluki Abu Thayyib dan memiliki beberapa karya seperti Ibthal al-Qiyas dan Na'at al-Hikmah fi Ushul al-Fiqh. ${ }^{12}$

Ibn Hazm selain merupakan pengikut madzhab Dzahiriyah yang paling setia. Beliau pula yang dinilai sebagai pengikut yang telah menguatkan berbagai persoalan furu' yang diungkapkan oleh Dawud al-Dzahiri dengan berbagai dalil sebagai justfikasinya. Di samping itu pula, Ibn Hazm berhasil menjawab berbagai kritik yang dialamatkan kepada Abu Dawud al-Dzahiri oleh para pengkritiknya. ${ }^{13}$ Sekalipun Ibn Hazm tercatat sebagai pelanjut pemikiran Abu Dawud al-Dzahiri, perlu ditegaskan bahwa Ibn Hazm pada awalnya adalah seorang ilmuwan terpelajar yang melabuhkan dirinya pada madzhab Maliki, di mana madzhab tersebut adalah madzhab resmi penguasa saat itu. Kemudian Ibn Hazm beralih kepada madzhab Syafi'i dan menjadi pengikutnya dalam selang waktu yang cukup lama. Setelah pengembaraannya dalam belantara madzhab fiqih, pada akhirnya Ibn Hazm memantapkan dirinya sebagai pengikut setia dan bahkan ia tampil sebagai penerus pemikiran-pemikiran Abu Dawud al-Dzahiri. Karena itu, tidak mengherankan jika madzhab al-Dzahiri seakan-akan lebih melekat pada diri Ibn Hazm dibandingkan dengan penisbatannya kepada Abu Dawud al-Dzahiri yang tidak lain adalah sebagai pencetusnya. ${ }^{14}$

Perjuangan ibn Hazm dalam mengembangkan pemikiran Abu Dawud al-Dzahiri yang terwujud dalam satu aliran pemikiran hukum Islam yang disebut madzhab alDzahiriyah harus menghadapi berbagai tantangan, tidak hanya tantangan dari para "oposisi" terhadap madzhab Dzahiriyah ini, tetapi tantangan yang dimaksudkan adalah evolusi sejarah. Dalam artian, evolusi sejarahlah yang akan menentukan apakah pemikiran-pemikiran cemerlang Ibn Hazm dapat diterima sebagai madzhab "resmi" di samping madzhab empat (Maliki, Hanafi, Syafi'i dan Hanbali) yang telah begitu

\footnotetext{
${ }^{10}$ Zahrah, 511.

${ }^{11}$ Zahrah, 511.

12 Arif Khalil Muhammad Abu Ayd, Al-Imam Dawud al-Dzahiri Wa Atsaruhu Fi al-Fiqh al-Islami (Kuwait: Dar al-Arqam, 1984), 115.

13 Abdul Hamid Husain al-Samara'i, “Ta'tsir al-Wad' al-Siyasi Ala al-Madzhab al-Dzahiri," Majallah AlJamiah Tigris Li al-Ulum al-Insaniyah 16, no. 2 (2009): 72.

14 Muhammad Abdullah Abu Shu'aylayk, Al-Imam Ibn Hazm al-Dzahiri: Imam Ahl al-Andalus (Damaskus: Dar al-Qalam, 1995), 35.
} 
popular atau bahkan ia hanya dapat menjadi madzhab "pinggiran" yang tidak banyak diminati. Tumbuh kembangnya aliran pemikiran hukum -termasuk pemikiran hukum madzhab Dzahiriyah - harus tunduk pada kenyataan sosiologis yang setidaknya dapat dilihat dari ada dan tidaknya organisasi sosial atau gerakan masyarakat yang dapat menerima atau menolak suatu pemikiran hukum yang ditelorkan ke dalam belantara pertarungan pemikiran. ${ }^{15}$

Melalui analisis sosiologis di atas, "kegagalan" madzhab Dzahiriyah dalam menyamai madzhab utama yang dikenal dengan madzahib al-Arba'ah juga dapat ditelaah melalui apa yang disebut oleh Atho Mudzhar sebagai gerakan sosial organisasi masyarakat sebagai konsumen hukumnya. Kaitannya dengan persoalan ini, rupanya dapat diamini analisis yang dilakukan oleh Arif Khalil Muhammad Abu Ayd. Menurutnya, terdapat beberapa faktor yang turut menghalangi kontestasi pemikiran Madzhab Dzahiriyah dalam arena percaturan fiqh Islam. Faktor yang dimaksudkan adalah popularitas madzahib al-arba'ah yang telah demikian tersiar dan dianut oleh kaum muslimin. ${ }^{16}$ Selain faktor tersebut, adanya penolak madzhab Dzahiriyah dalam istinbath hukumnya terhadap penggunaan qiyas yang secara otomatis berbeda dengan mayoritas ulama sehingga menimbulkan berbagai "serangan" terhadap madzhab tersebut. Faktor yang tidak kalah pentingnya adalah terkait dengan pandangan Dawud al-Dzahiri tentang al-Quran yang menurutnya adalah makhluk, serta pandangan fiqihnya yang disinyalir tidak memuliakan al-Quran sebagai kalam Allah, terbukti dengan pendapatnya bahwa orang yang berhadas besar baik disebabkan karena janabah atau haid, boleh menyentuh dan membaca al-Qur'an. ${ }^{17}$

\section{Metodologi Istinbath al-Ahkam Madzhab Dzahiriyah}

Stagnasi madzhab Dzahiriyah dalam belantara kajian fiqh Islam sebagaimana banyak diulas dalam berbagai kitab tentang sejarah Islam (tarikh al-tasyri' al-Islami) disinyalir karena -salah satunya -disebabkan oleh penolakan madzhab ini terhadap qiyas sebagai salah satu piranti metodologis dalam istinbath al-ahkam yang sejatinya di kalangan jumhur ulama, qiyas telah ditetapkan sebagai mashadir al-tasyri' al-islami. ${ }^{18}$ Analisis di atas memang dapat dibenarkan dengan menelaah pandangan-pandangan ibn Hazm sebagai pelanjut setia madzhab Dzahiriyah terhadap sumber hukum Islam. Di dalam salah satu karyanya, dengan tegas ibn Hazm menyatakan bahwa tidaklah dihalalkan bagi seseorang untuk menentukan hukum melalui metode qiyas, ra'yu dan istihsan serta tidak juga didasarkan pada pernyataan seseorang selain Rasululullah Saw., yang tidak berkesesuaian dengan al-Quran ataupun hadis yang sahih karena semua itu berarti menghukumi sesuatu hanya didasarkan pada prasangka semata. ${ }^{19}$

15 Dalam pandangan M. Atho Mudzhar, kajian sosiologis terhadap hukum Islam, di samping mengkaji gerakan sosial yang mendukung atau menolak suatu pemikiran, dapat juga mengambil porsi dalam kajian tentang Pengaruh hukum Islam terhadap masyarakat dan perubahan masyarakat, pengaruh perubahan dan perkembangan masyarakat terhadap perkembangan pemikiran hukum Islam serta kajian seputar pola interaksi masyarakat di sekitar hukum Islam. Dikutip dalam, A. Asmawi, "Rasionalisasi Tradisi Bermazhab Menurut Shah Wali Allah," Epistemé: Jurnal Pengembangan Ilmu Keislaman 8, no. 1 (June 4, 2013): 48-49, https://doi.org/10.21274/epis.2013.8.1.29-52.

${ }^{16}$ Abu Ayd, Al-Imam Dawud al-Dzahiri Wa Atsaruhu Fi al-Fiqh al-Islami, 146.

${ }^{17}$ Abu Ayd, 7.

18 'Abdul Qadir Syaibah, Itsbat Al-Qiyas Fi al-Syari'ah al-Islamiyah Wa al-Radd 'ala Munkirih (Riyadh, 1996), 21.

19 Abu Muhammad Ali Ibn Ahmad Ibn Sa’id Ibn Hazm al-Andalusi, Al-Muhalla Bi al-Atsar, vol. 8 (Beirut: Dar al-Kutub Ilmiyah, 2003), 429; Dalam karyanya yang lain, Ibn Hazm menyatakan "wa la 
Sementara menurut Ibn Hazm, Allah telah memberikan peringatan agar tidak menjadikan prasangka sebagai "dalil". Dalam hal ini Ibn Hazm mengutip ayat al-Quran maupun hadis Nabi untuk menguatkan pendapatnya. Ayat yang dikutip adalah ayat 36 dalam surat Yunus yang menyebutkan secara tegas bahwa prasangka itu tidak memberikan kegunaan sedikitpun untuk mencapai kebenaran. ${ }^{20}$ Begitu juga ayat 23 dalam surat al-Najm yang mengecam mereka yang berpegang pada prasangka dan hawa nafsu. ${ }^{21}$ Bahkan Ibn Hazm juga mengutip hadis Nabi yang menyebutkan bahwa prasangka itu sebenarnya adalah pernyataan yang paling dusta. Hal ini berdasarkan riwayat Abu Hurairah yang menyatakan bahwa Rasulullah Saw., bersabda, إِيَّاكُمْ وَالظَّنَّ فَإِنَّ (Jauhilah oleh kalian berprasangka karena sesungguhnya prasangka itu adalah sedusta-dustanya pembicaraan). ${ }^{22}$

Penolakan Ibnu Hazm terhadap qiyas dan lain sebagainya, erat kaitannya dengan pandangan Ibn Hazm bahwa setiap peristiwa hukum yang terjadi dapat ditemukan nash yang mengaturnya. Menurutnya, hukum Allah terbagi menjadi tiga bagian, yaitu adakalanya fardhu, haram ataupun mubah. Sesuatu yang diperintahkan oleh syari' untuk dilakukan maka hukumnya adalah fardhu. Sebaliknya, sesuatu yang diperintahkan untuk ditinggalkan maka itu berarti haram. Sementara peristiwa hukum yang tidak diperintahkan ataupun tidak dilarangnya oleh nash, maka itu berarti dimaafkan. Maka jika ada yang mengatakan sesuatu itu haram, maka kami -kata Ibn Hazm -akan menanyakan ada tidaknya nash atau ijma' yang mendukungnya. Jika tidak ada, maka saya katakakan itu mubah. Begitu sebaliknya, jika adanya menyatakan sesuatu itu wajib, maka kami akan menanyakan tentang perintah tegas dari nash, sehingga jika tidak ditemukan maka itu pun hukumnya mubah. ${ }^{23}$

Praktis yang menjadi sumber hukum dalam kerangka istinbath al-ahkam madzhab Dzahiriah adalah al-Quran dan hadis yang disebut dengan al-nash. Al-Quran adalah wahyu yang dibaca (al-wahy al-matluw) sedangkan hadis adalah wahyu yang diriwayatkan (al-wahy al-marwiy). Keduanya, al-Quran dan hadis menurut Ibn Hazm berfungsi saling melengkapi (al-Quran wa al-Sunnah juz'ayn aw qismayn kilahuma mukmil li al-akhar). ${ }^{24}$ Selain al-Quran dan hadis, madzhab Dzahiriyah juga bersandar pada ijma'. Bahkan dinyatakan bahwa kesepakatan umat Nabi Muhammad atas suatu hukum dinilai sebagai hujjah syar'iyyah yang bersifat qat'i dan wajib untuk diamalkan.

yahillu al-hukm bi al-Qiyas fi al-din wa al-qawl bihi batil, maqthu'un 'ind Allah". Abu Muhammad Ali Ibn Ahmad Ibn Sa'id Ibn Hazm al-Andalusi, Al-Nubadz Fi Ushul al-Fiqh al-Dzahiri (Beirut: Dar Ibn Hazm, n.d.), 98.

${ }^{20}$ Ayatnya berbunyi:

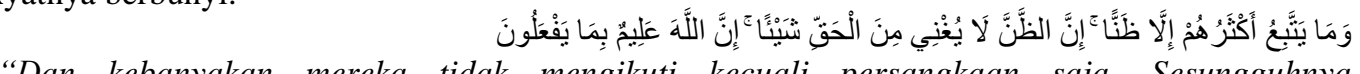
"Dan kebanyakan mereka tidak mengikuti kecuali persangkaan saja. Sesungguhnya persangkaan itu tidak sedikitpun berguna untuk mencapai kebenaran. Sesungguhnya Allah Maha Mengetahui apa yang mereka kerjakan”.

${ }^{21}$ Di dalam ayat tersebut, Allah berfirman:

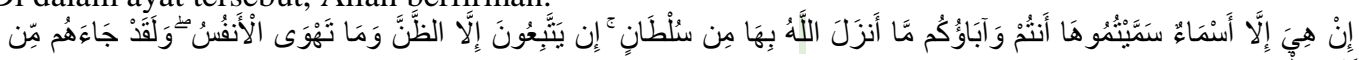

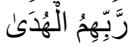

"Itu tidak lain hanyalah nama-nama yang kamu dan bapak-bapak kamu adakan; Allah tidak menurunkan suatu keteranganpun untuk (menyembah)nya. Mereka tidak lain hanyalah mengikuti sangkaan-sangkaan, dan apa yang diingini oleh hawa nafsu mereka dan sesungguhnya telah datang petunjuk kepada mereka dari Tuhan mereka".

${ }^{22}$ Muhammad Ibn Isma'il al-Bukhari, Shahih Al-Bukhari, vol. 5 (Damaskus: Dar Ibn Katsir, 1996), 250.

${ }^{23}$ Abu Muhammad Ali Ibn Ahmad Ibn Sa'id Ibn Hazm al-Andalusi, Ibthal Al-Qiyas Wa al-Ra'y Wa alIstihsan Wa al-Taqlid Wa al-Ta'lil (Damaskus: Matba'ah Jami'ah Damaskus, 1960), 45-46.

${ }^{24}$ Nuruddin al-Khadimi, Al-Dalil 'Ind al-Dzahiriyah (Damaskus: Dar Ibn Hazm, 2000), 77. 
Namun dalam pandangan Ibn Hazm, ijma' yang dimaksud sebagai sandaran hukum yang bersifat qat 'i adalah ijma' yang berupa kesepakatan seluruh sahabat Nabi dan tidak seorang sahabat pun yang mengingkarinya. Dalam hal ini, Ibn Hazm telah memberikan klasifikasi ijma' menjadi ijma' seluruh kaum muslimin, ijma' para sahabat nabi dan ijma para ahl al- 'ilm. Pada peringkat kedua inilah, ijma' yang dinilai oleh ibn Hazm sebagai ijma' yang berimplikasi pada status hukum qat'i yang tidak boleh dilanggarnya. ${ }^{25}$

Rasionalisasi dari sumber hukum di atas menurut Ibn Hazm karena di dalam alQuran ditemukan adanya kewajiban mematuhi semua perintah Allah dan Nabi-Nya serta aturan-aturan yang tercapai padanya kesepakatan semua ulama (ijma'). Menurutnya, Allah mempersamakan ketiga sumber ini dalam hal sama-sama wajib dipatuhi. ${ }^{26}$ Namun jika di dalam ketiga sumber itu tidak ditemukan rumusan hukum atas suatu persoalan, maka di dalam madzhab al-Dzahiri diperkenalkan apa yang disebut dengan al-Dalil, yang sebenarnya menurut Khatib al-Baghdadi, tidaklah jauh berbeda dengan qiyas. ${ }^{27}$ Penilaian Khatib al-Baghdadi dapat dibenarkan dari sisi penggunaan al-dalil yang secara operasional memiliki langkah teoretis yang tidak jauh berbeda. Contoh yang dapat diangkat adalah pengharaman khamar. Dalam istinbath jumhur ulama, dengan berpegang pada ketentuan bahwa "kullu muskirin haramun", maka keharaman khamar didasarkan pada 'illatnya yaitu memabukkan yang kemudian diperluas kepada semua minuman yang memabukkan. Sementara dalam kerangka istinbath madzhab Dzahiriyah, keharaman khamar dan segala hal yang memabukkan tidak didasarkan pada 'illat hukum melainkan pada ketentuan teks yang diletakkan sebagai premis mayor dan minor yang kemudian ditarik sebuah kesimpulan. ${ }^{28}$

Secara operasional berikut adalah metode penarikan kesimpulan dari hadis yang berbicara tentang keharaman khamar dalam kerangka metodologi penalaran hukum madzhab Dzahiriyah. Hadis Nabi yang berbunyi "setiap yang memabukkan adalah khamar dan setiap khamar adalah haram" menurut Ibn Hazm mengandung dua muqaddimah yakni muqaddimah syughra yaitu kalimat "setiap yang memabukkan adalah khamar" dan muqaddimah qubra yaitu kalimat "setiap khamar adalah haram". Dari dua premis demikian dapat diambil sebuah natijatul hukm bahwa setiap yang memabukkan adalah haram. ${ }^{29}$ Proses penalaran seperti dikemukakan di atas, dalam ilmu logika disebut sebagai silogisme, yaitu proses pengambilan kesimpulan dari dua premis, yang dalam bahasa Arab dinyatakan sebagai qiyas. ${ }^{30}$ Walau demikian, penalaran sebagaimana ditunjukkan dalam metodologi fiqih Ibn Hazm menurut al-Syathibi tidak dapat dipersamakan begitu saja dengan proses istinbath qiyasi sebagaimana dikenal dalam kajian ushul fiqih, sebab yang dimaksud dengan dua premis dalam kerangka metodologi Ibn Hazm bukanlah teori yang dikenal dalam ilmu mantiq. Mengambil

\footnotetext{
${ }^{25}$ Ibn Hazm al-Dzahiri, Maratib al-Ijma' fi al-'Ibadat wa al-Mu'amalat wa al-I'tiqadat (Beirut: Dar Ibn Hazm, 1998), 9-13; Muhammad Ibn Syadid Ibn Syidad al-Tsaqafi, Ilzamat Ibn Hazm al-Dzahiri li alFuqaha' min Khilal Kitabih al-Muhalla: Dirasah wa Taqwim”, Disertasi (Makkah: Jami'ah Umm alQura, 2011), 42.

${ }^{26}$ Abdul Hadi, "Istinbat Hukum Islam Perspektif Az-Zahiri”, NURANI, Vol. 14, No. 2, Tahun 2014, 40.

${ }^{27}$ Asmawi, Fiqh Zahiriyah, 67.

${ }^{28}$ Nur Khoirin, "Penalaran Ushul Fiqh Ibnu Hazm (Analisis Penolakan 'Illat dan Qiyas sebagai Dalil Hukum Islam", Yudisia: Jurnal Pemikiran Hukum dan Hukum Islam, Vol. 9, No. 1, $2018,80$.

29 Asmawi, Studi Hukum Islam: Dari Tekstualis-Rasionalis sampai Rekonsiliatif (Yogyakarta: Teras, 2012), 75.

30 Hasbi Ash-Shiddieqy, Pokok-Pokok Pegangan Imam-Imam Madzhab dalam Membina Hukum Islam (Jakarta: Bulan Bintang, 1974), 351.
} 
konklusi dari dua muqaddimah tersebut hanyalah sebagai thariqah yang paling mendekatkan untuk mencapai kesimpulan hukum-hukum syara'. ${ }^{31}$

Dalam pandangan Ibn Hazm, al-dalil yang digunakan sebagai piranti ijtihad dalam madzhab Dzahiriyah bukanlah dalil yang berdiri sendiri melainkan ia merupakan dalil yang diambil dari nash dan ijma'. Dengan kata lain, al-dalil dipahami secara langsung dari nash dan ijma' bukan melalui proses analogi seperti yang dikenal dalam qiyas. ${ }^{32}$ Hal tersebut dapat dilihat dari pernyataan Ibn Hazm pada saat mengakhiri pembahasannya tentang al-dalil yang digunakan sebagai piranti ijtihadnya. Dalam hal ini ia mengatakan, dalil-dalil tersebutlah yang kami gunakan dalam melakukan istinbath hukum. Kesemuanya merupakan makna dan pemahaman terhadap nash dan sama sekali tidak keluar dari koridor nash. ${ }^{33}$

\section{Nafkah dan Kepemimpinan Rumah Tangga Perspektif Fiqh Dzahiriyah}

Nafkah menjadi salah satu indikator berubahnya hukum pernikahan dari mandub menjadi wajib dan seterusnya. ${ }^{34}$ Dengan kata lain, kemampuan seorang laki-laki dalam kedudukannya sebagai seorang suami dalam memberikan nafkah kepada seorang perempuan dalam kapasitasnya sebagai isteri dijadikan sebagai titik tolak untuk menentukan status hukum pernikahan. Dalam hal ini, menurut Ibn Hazm, mengapa nafkah ditempatkan begitu penting dalam kehidupan manusia -begitu pula halnya dalam hal perkawinan - menurutnya tentu saja didasari oleh satu kenyataan bahwa setiap manusia, baik laki-laki maupun perempuan, anak kecil maupun mereka yang telah mencapai usia dewasa pastilah tidak dapat melepaskan diri dari kebergantungannya terhadap nafkah yang dapat menunjang kehidupannya. ${ }^{35}$

Konsep nafkah menjadi persoalan yang sangat luas dalam konteks kehidupan manusia. Murtadha Mutahhari kemudian memerinci persoalan kewajiban nafkah ke dalam tiga bentuk dengan karakteristiknya masing-masing. Pertama, nafkah yang menjadi kewajiban seorang pemilik kepada apa yang dimilikinya. Dalam hal ini termasuk juga kewajiban memberikan nafkah dari sang pemilik kepada hewan peliharaannya. Nafkah dalam kategori ini disebut oleh Mutahhari sebagai nafkah almalikiyah wa al-mamlukiyah. Kedua, nafkah yang menjadi kewajiban seseorang kepada anak-anaknya yang masih kecil atau mereka yang hidup dalam garis kemiskinan. Termasuk juga kewajiban memberikan nafkah kepada kedua orang tua manakala mereka tergolong sebagai fakir miskin. ${ }^{36}$

Adapun kategori ketiga, nafkah yang menjadi kewajiban seorang suami kepada isterinya. Kategori ketiga ini menurut Mutahhari tidak dikategorikan sebagai nafkah almalikiyah wa al-mamlukiyah dan tidak juga disebabkan oleh keadaan seorang isteri sebagai orang yang fakir ataupun orang yang lemah. ${ }^{37}$ Dalam hal ini jelaslah bahwa nafkah yang menjadi kewajiban seorang suami kepada isterinya adalah semata-mata

\footnotetext{
${ }^{31}$ Asmawi, Studi Hukum Islam, 75.

${ }^{32}$ Abu Shu'aylayk, al-Imam Ibn Hazm, 71.

${ }^{33}$ Abu Shu'aylayk, al-Imam Ibn Hazm, 73.

${ }^{34}$ Menurut jumhur ulama, hukum pernikahan adalah mandub, sementara menurut madzhab Dzahiriyah pernikahan dihukumi wajib atau dalam pandangan sebagian ulama Malikiyah, hukum pernikahan adakalanya wajib, mubah atau bahkan mandub tergantung kepada kondisi kekhawatiran seseorang untuk tidak terjerumus ke dalam jurang kemaksiatan. Muhammad Ibn Ahmad Ibn Muhammad Ibn Rusyd alHafid, Bidayat al-Mujtahid wa Nihayat al-Muqtashid, Vol. 3 (Kairo: Maktabah Ibn Taymiyah, 2001), 7.

${ }^{35}$ Ibn Hazm, Al-Muhalla, Vol. 9, 266.

${ }^{36}$ Murtadha Mutahhari, Nidzam Huquq al-Mar'ah fi al-Islam (Iran: Dzawi al-Qurba, 2005), 250.

${ }^{37}$ Murtadha Mutahhari, Nidzam Huquq al-Mar'ah, 251.
} 
sebagai konsekuensi dari akad yang dilaksanakannya dan berimplikasi pada pertukaran antara hak dan kewajiban yang melekat pada suami isteri. ${ }^{38}$ Dalam istilah Ibn Hazm, kewajiban nafkah telah melekat pada seorang suami sejak dilangsungkannya akad nikah, baik terhadap perempuan yang kaya ataupun faqir, perempuan yatim atau tidak, perawan ataupun janda, maupun perempuan yang merdeka atau budak. Dasar yang dijadikan sebagai basis argumentasinya adalah hadis Nabi yang disabdakan pada saat beliau melaksanakan haji wada' di mana beliau menyatakan bahwa suami memiliki kewajiban untuk memberikan nafkah dan pakaian yang layak kepada seorang perempuan. Bagi Ibn Hazm, hadis tersebut menjadi dalil bahwa nafkah telah menjadi kewajiban bagi seorang suami sejak dilangsungkannya akad. ${ }^{39}$ Hadis yang dimaksudkan oleh Ibn Hazm secara lengkap berbunyi: ${ }^{40}$

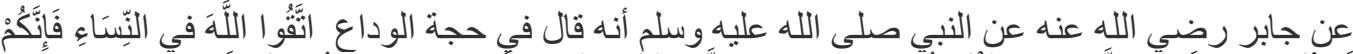

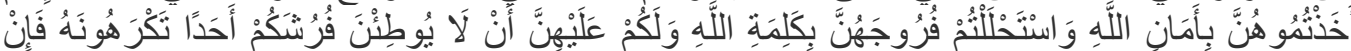

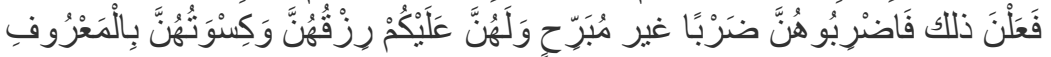

"Hendaklah kalian bertakwa kepada Allah terhadap isteri kalian, karena kalian mengambil mereka dengan perlindungan Allah dan menghalalkan kehormatan mereka dengan kalimat Allah. Dan kalian memiliki hak yang menjadi kewajiban mereka untuk tidak mempersilahkan seorangpun di ranjangnya orang yang kalian benci. Jika mereka lakukan hal itu, maka pukullah mereka dengan pukulan yang tidak melukai. Dan mereka memiliki hak yang menjadi kewajiban kalian berupa nafkah dan pakaian dengan cara yang ma'ruf."

Penjelasan senada juga dapat ditemukan dalam hadis lain, di mana ada seorang perempuan yang mengadu kepada Nabi perihal suaminya yang dinilai enggan untuk memberikan nafkah. Orang yang dimaksudkan adalah Hindun binti 'Utbah yang tidak lain adalah isteri Abu Sufyan. Dia menemui baginda Nabi lalu berkata, wahai Rasulullah, sesungguhnya Abu Sufyan adalah orang yang kikir, dia tidak memberiku nafkah yang cukup untukku dan anakku, kecuali dari hartanya yang aku ambil tanpa sepengetahuannya, apakah hal itu dibolehkan?' Maka Rasulullah bersabda, ambillah apa yang cukup bagimu dan untuk anakmu dengan cara yang ma'ruf. ${ }^{41}$ Adapun ukuran ma'ruf sebagaimana dijelaskan dalam hadis tersebut bagi ibn Hazm adalah sesuai dengan standar umum yang berlaku dalam kehidupan masyarakat. ${ }^{42}$

Sejalan dengan pernyataan Ibn Hazm bahwa nafkah menempati posisi yang sangat urgen dalam struktur kehidupan keluarga, maka seandainya laki-laki yang dibebani kewajiban untuk memberikan nafkah ternyata tidak mampu baik untuk menafkahi dirinya sendiri maupun nafkah yang harus diberikan kepada seorang isteri, sementara si isteri tergolong orang yang memiliki kecukupan dari sisi finansial, maka dalam konteks demikian menurut Ibn Hazm, isteri wajib menanggung nafkah suami dan tidak ada kewajiban bagi suami untuk mengembalikannya jika di kemudian hari ternyata suami

\footnotetext{
38 Abdussalam Ibn Muhammad al-Syuwa'ir, Atsar 'Amal al-Mar'ah fi al-Nafaqat al-Zawjiyah (Riyad: Jami'ah al-Imam Muhammad Ibn Sa'ud al-Islamiyah, 2011), 11.

${ }^{39}$ Ibn Hazm, Al-Muhalla, Vol. 9, 249.

${ }^{40}$ Abu al-Husain Muslim Ibn Hajjaj Ibn Muslim, Shahih Muslim (Riyad: Dar al-Salam, 2000), 633.

${ }^{41}$ Abu Abdillah Muhammad Ibn Ismail al-Bukhari, Shahih al-Bukhari (Damaskus: Dar Ibn Katsir, 2002), 1.365 .

${ }^{42}$ Ibn Hazm, Al-Muhalla, Vol. 9, 250.
} 
memiliki kemampuan finansial. ${ }^{43}$ Dasar yang digunakan oleh Ibn Hazm surat alBaqarah ayat 233 yang berbunyi:

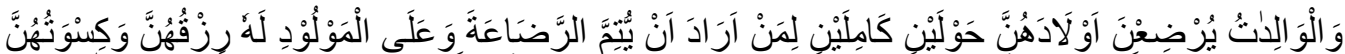

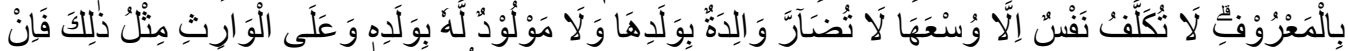

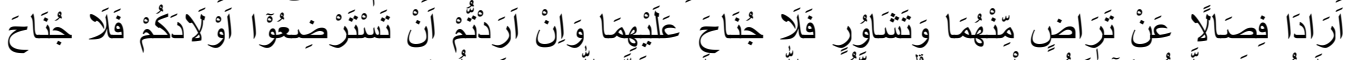

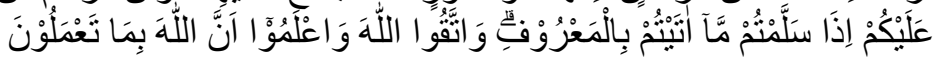

"Dan ibu-ibu hendaklah menyusui anak-anaknya selama dua tahun penuh, bagi yang ingin menyusui secara sempurna. Dan kewajiban ayah menanggung nafkah dan pakaian mereka dengan cara yang patut. Seseorang tidak dibebani lebih dari kesanggupannya. Janganlah seorang ibu menderita karena anaknya dan jangan pula seorang ayah (menderita) karena anaknya. Ahli waris pun (berkewajiban) seperti itu pula. Apabila keduanya ingin menyapih dengan persetujuan dan permusyawaratan antara keduanya, maka tidak ada dosa atas keduanya. Dan jika kamu ingin menyusukan anakmu kepada orang lain, maka tidak ada dosa bagimu memberikan pembayaran dengan cara yang patut. Bertakwalah kepada Allah dan ketahuilah bahwa Allah Maha Melihat apa yang kamu kerjakan".

Ayat di atas menurut Ibn Hazm menjelaskan kewajiban nafkah kepada ahli waris

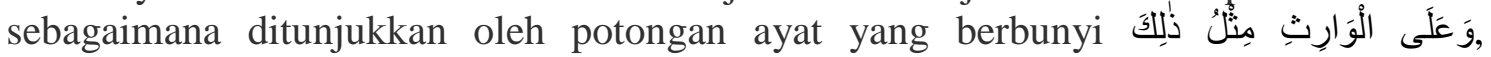
sementara isteri menurutnya adalah golongan yang termasuk ke dalam ahli waris. Penafsiran ini menurut Ibn Hazm didasarkan pada pendapat sahabat Ali yang memberikan penafsiran terhadap potongan ayat dengan "al-zawjat waritsatun fa'alayha nafaqatuh bi nash al-Quran." Dalam kondisi seorang suami tidak mampu memberikan nafkah, maka isteri dapat bertindak sebagai pemberi nafkah jika memang ia tergolong sebagai orang yang mampu secara finansial. ${ }^{44}$ Sedangkan dalam pandangan mufassir yang lain, al-warits yang dimaksudkan dalam ayat tersebut adalah seorang anak. Demikian pendapat yang dikemukakan oleh Muhammad Ibn Jarir al-Thabari. Bahkan ada pendapat yang mengaitkan penafsiran ayat tersebut terhadap larangan bagi orang tua yang ditinggalkan untuk melakukan perbuatan yang dapat membahayakan masa depan seorang anak. Dengan kata lain, larangan bagi seorang ibu untuk menyia-nyiakan anak yang telah ditinggalkan oleh ayah sebagai pemberi nafkah terhadap seorang anak maupun terhadap seorang ibu. ${ }^{45}$

Sekalipun Ibn Hazm begitu ketat dalam menempatkan kewajiban memberikan nafkah kepada seorang isteri sebagai kewajiban bagi seorang suami, menariknya adalah implikasi dari kewajiban tersebut yang tidak sampai pada penobatan seorang laki-laki sebagai makhluk istimewa dibandingkan perempuan sehingga menutup kemungkinan perempuan menjadi seorang pemimpin -sebagaimana akan ditunjukkan dalam uraian berikutnya -, tentu saja pandangan ini berbeda dengan pendapat para ulama pada saat mereka menafsirkan kepemimpinan laki-laki dalam rumah tangga yang secara umum mendasarkan pada bunyi ayat 34 dalam surat al-Nisa. Di dalam surat al-Nisa ayat 34 Allah berfirman:

\footnotetext{
${ }^{43}$ Ibn Hazm, Al-Muhalla, Vol. 9, 254.

${ }^{44}$ Ibn Hazm, Al-Muhalla, Vol. 9, 254.

45 Abu Abdillah Muhammad Ibn Abi Bakr al-Qurtubi, al-Jami' li Ahkam al-Quran, Vol. 4 (Beirut: Muassasah al-Risalah, 2006), 121.
} 
58 | De Jure: Jurnal Hukum dan Syari’ah, Vol. 11 No. 1 Tahun 2019

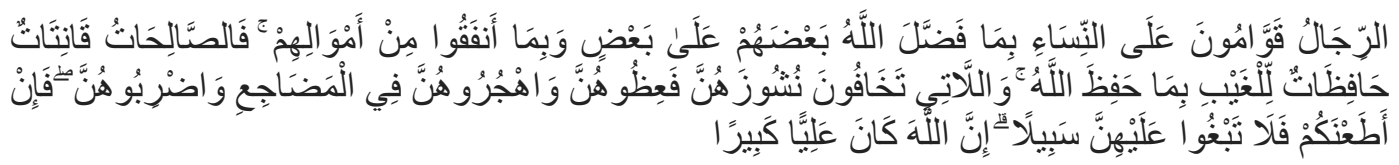

"Kaum pria adalah pemimpin bagi kaum wanita, karena Allah telah melebihkan sebagian mereka (pria) atas sebagian yang lain (wanita), dan karena mereka (pria) telah menafkahkan sebagian dari harta mereka. Maka dari itu, wanita yang salihah ialah yang taat kepada Allah subhanahu wa ta'alaagi memelihara diri ketika suaminya tidak ada, karena Allah telah memelihara (mereka). Wanitawanita yang kalian khawatirkan nusyuznya, maka nasihatilah mereka, dan jauhilah mereka di tempat tidur, dan pukullah mereka. Jika mereka menaati kalian, janganlah kalian mencari-cari jalan untuk menyusahkan mereka. Sesungguhnya Allah Mahatinggi lagi Mahabesar."

Ayat di atas dijadikan sebagai dalil bahwa seorang laki-laki menjadi pimpinan rumah tangga disebabkan oleh kelebihan yang telah dianugerahkan oleh Allah baik anugerah yang bersifat kasbiyyah ataupun wahbiyah. ${ }^{46}$ Mengikuti alur penafsiran ini maka perempuan sebagai orang yang terpimpin dibebani oleh berbagai kewajiban yang menunjukkan betapa agungnya posisi laki-laki sebagai pemimpin di dalam rumah tangga. Keagungan posisi laki-laki di atas perempuan dapat disimak dari pengandaian akan perintah bagi seorang perempuan untuk bersujud kepada sang suami, andai saja diperbolehkan bagi seseorang untuk menyembah kepada manusia. Tegasnya, kebaktian kepada laki-laki sebagai suami dijadikan sebagai jalan bagi seorang perempuan untuk menuju sorga, karenanya, pembangkangan terhadap suami dinilai sebagai indikator ditolaknya ibadah termasuk shalat seorang perempuan. ${ }^{47}$

Penafsiran yang lebih tegas terhadap ayat di atas dengan mengaitkan kepemimpinan laki-laki atas perempuan karena laki-laki telah memberikan nafkah kepada perempuan dapat disimak dari penafsiran Syeikh Nawawi Banten. Menurutnya, laki-laki sebagai penguasa dalam membina perilaku perempuan disebabkan oleh kelebihan yang telah dianugerahkan oleh Allah kepada mereka berupa kesempurnaan akal, kecerdasan dalam berpikir, kemampuan maksimal dalam melaksanakan pekerjaan serta dalam hal ketaatan. Karena itu, menurut Syeikh Nawawi, mereka inilah yang pantas mengemban tugas kenabian dan kepemimpinan. Selain itu, laki-laki sebagai pemimpin bagi seorang perempuan disebabkan laki-lakilah yang telah memberikan nafkah kepada seorang perempuan. ${ }^{48}$

Dengan demikian, maka ukuran perempuan yang shalihah menurut Syeikh Nawawi adalah mereka yang mampu berbuat baik serta bersikap taat kepada seorang suami, serta mereka yang mampu menjaga diri maupun harta seorang suami pada saat ketiadaannya sebagai imbalan terhadap kewajiban seorang suami yang telah ditetapkan oleh Allah berupa perintah untuk bersikap adil dan mempergauli isteri-isterinya dengan baik, dan kewajiban lain yang tidak kalah pentingnya berupa kewajiban untuk memberikan nafkah. ${ }^{49}$ Uraian di atas menunjukkan titik beda keterkaitan nafkah dan

\footnotetext{
${ }^{46}$ Mahmud al-Alusi, Ruh al-Ma'ani fi Tafsir al-Quran al-Adzim wa Sab'u al-Matsani, Vol. 3 (Beirut: Dar al-Fikr, 2001), 24.

47 'Imaduddin Abu al-Naja, Matn al-Arba'in al- 'Imadiyah fi al-Huquq al-Zawjiyah (Mesir: t.tp.: t.th.), 13 dst.

${ }^{48}$ Muhammad Ibn 'Umar Nawawi al-Jawi, Mirah Labid li Kasyf Ma'na Qur'an al-Majid, Vol. 1 (Beirut: Dar al-Kutub al-'Ilmiyah, 1997), 195.

${ }^{49}$ Muhammad Ibn ‘Umar Nawawi al-Jawi, Mirah Labid, 195.
} 
problem kepemimpinan dalam rumah tangga antara pemahaman Ibn Hazm dan beberapa penafsiran yang telah diuraikan di atas. Jika mereka memahami kepemimpinan dalam rumah tangga adalah hak laki-laki karena ia -di antaranya -telah menjadi "penjamin" nafkah, maka dalam pandangan Ibn Hazm tidak selalu demikian. Sebab, beban nafkah dalam keluarga tidak mutlak hanya kepada laki-laki namun ada kemungkinan seorang perempuan dinobatkan sebagai pemberi nafkah dalam kondisi laki-laki tidak mampu menyediakan kecukupan finansial sementara si isteri tergolong sebagai orang yang kaya. Karena itu pula, persoalan kepemimpinan menjadi tidak mutlak hanya milik laki-laki. Dalam hal ini Ibn Hazm berpegang pada asas persamaan di depan hukum yang secara otomatis juga berimplikasi pada persamaan antara hak dan kewajiban. Asas ini menurutnya telah menjadi kesepakatan di antara para ulama. ${ }^{50}$

Atas dasar pandangan ini, ayat tentang kepemimpinan dalam rumah tangga -surat al-Nisa ayat 34 -yang ditafsirkan oleh para ulama sebagai bentuk keistimewaan lakilaki sehingga seakan-akan menutup pintu bagi kepemimpinan perempuan bagi ibnu Hazm dipahami sebagai bentuk kepemimpinan yang bersifat fungsional dan kondisional. ${ }^{51}$ Dalam konteks yang lebih luas, bagi Ibn Hazm tidak ada halangan bagi seorang perempuan untuk memangku jabatan hakim. ${ }^{52}$ Bahkan dalam karyanya yang lain, Ibn Hazm sampai pada kesimpulan bahwa seorang perempuan dimungkinkan untuk memangku jabatan kenabian. Sementara pendapat para ulama yang menolak kemungkinan perempuan diangkat sebagai nabi karena berdasarkan pada surat alAnbiya ayat $7 .{ }^{53}$ Namun dalam pandangan Ibn Hazm, ayat tersebut khusus berbicara tentang jabatan kerasulan bukan kenabian. ${ }^{54}$

Bagi Ibn Hazm, siapapun yang diberikan wahyu oleh Allah untuk melakukan suatu perbuatan, maka ia adalah nabi, mengingat istilah tersebut berasal dari kata alanba' wa al-I'lam. Dalam kategori demikian, maka beberapa perempuan yang disebut di dalam al-Quran seperti ibunda Nabi Ishaq yang diberikan kabar bahagia oleh Allah akan kelahiran Nabi Ishaq, maupun kisah yang dialami oleh Maryam akan kelahiran putranya serta perintah Allah kepada ibunda Nabi Musa untuk menghayutkannya di aliran sungai, mereka semua tergolong sebagai nabi, dalam arti mendapat wahyu dari Allah akan suatu hal yang harus dilakukannya. ${ }^{55}$ Menyimak pandangan Ibn Hazm sebagaimana di atas, nyatalah bahwa pola pikir tekstualis madzhab Dzahiriyah tidak selamanya berimplikasi pada pemikiran fiqih yang tidak kompatibel dengan tuntutan zaman. Justeru dalam kasus persoalan nafkah dan problem kepemimpinan perempuan ini, produk fiqih Dzahiriyah memberikan peluang kesetaraan perempuan yang selama ini memang menjadi konsen dari para pemikir yang berupaya mewujudkan hubungan antara laki-laki dan perempuan dalam hukum keluarga yang tidak bersifat patriarkhis. ${ }^{56}$

\footnotetext{
${ }^{50}$ Ibn Hazm, Al-Muhalla, Vol. 6, 412.

${ }^{51}$ Asmawi, Fiqh Zahiriyah, 74.

52 Ibn Hazm, Al-Muhalla, Vol. 8, 527.

${ }^{53}$ Di dalam surat al-Anbiya' ayat 7, Allah berfirman:
}

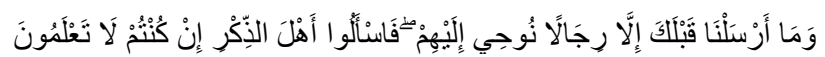
"Kami tiada mengutus rasul-rasul sebelum kamu (Muhammad), melainkan beberapa orang-lakilaki yang kami berikan wahyu kepada mereka, maka tanyakanlah olehmu kepada orang-orang yang berilmu, jika kamu tidak mengetahui."

${ }^{54}$ Mahmud 'Ali Himayah, Ibn Hazm wa Manhajuh fi Dirasat al-Adyan (t.tp.: Dar al-Ma'arif, 1983), 238.

${ }^{55}$ Himayah, Ibn Hazm, 239-240.

${ }^{56}$ Sebut saja misalnya upaya teoretis yang diperkenalkan oleh Faqihuddin Abdul Qadir dengan istilah Qira'ah Mubadalah. Melalui konstruk teori yang dibangunnya itu, Faqihuddin hendak mengenalkan cara baca terhadap teks suci dengan nuansa yang bersifat kesalingan (mubadalah) antara laki-laki dan 
Dengan demikian, istilah tekstualis yang dilekatkan kepada pola pikir madzhab Dzahiriyah bukanlah pola pikir yang serta merta menolak penggunaan akal di dalamnya, melainkan adanya titik tekan pada penggunaan al-Quran dan hadis sebagai sumber hukum bukan akal semata-mata. Bahkan bisa saja, pemikiran fiqih Ibn Hazm disejajarkan dengan pandangan pemikir yang dinilai sebagai pemikir moderat sekelas Muhammad 'Imarah yang menilai bahwa kepemimpinan laki-laki tidaklah didasarkan pada dzatnya sebagai laki-laki melainkan pada sifat kelelakiannya (al-rujulah) yang dengannya ia dapat menjadi pengayom bagi perempuan. Namun, karena sifat yang dimaksudkan tidaklah bersifat tetap melainkan berubah-ubah maka perempuanpun tidaklah diharamkan untuk menjadi pemimpin selama ia memiliki kapasitas yang dipersyaratkan dalam hal kepemimpinan. ${ }^{57}$

\section{Kesimpulan}

Hasil pembahasan dalam kajian ini secara jelas menunjukkan "sisi lain" dari pemikiran fiqih Dzahiriyah. Disebut "sisi lain" karena nalar tekstualis yang dilekatkan kepada aliran fiqh yang dikomandani Abu Dawud al-Dzahiri ini tidak jarang dinilai sebagai pemikiran yang jumud, dengan kata lain, ia tidak mampu bersanding dengan tuntutan zaman yang selalu berkembang. Namun melalui kajian ini, dengan memfokuskan pada persoalan nafkah dan kepemimpinan dalam rumah tangga, justeru pemikiran Ibn Hazm mengarah pada pola relasi antara laki-laki dan perempuan yang bersifat kemitraan. Di mana pola ini menjadi tuntutan para pegiat tentang kesetaraan gender termasuk dalam wilayah domestik. Pernyataan demikian dapat diketahui dari konsep nafkah yang dibangun dalam pemikiran fiqh Dzahiriyah. Sekalipun nafkah menjadi kewajiban bagi seorang laki-laki, namun adakalanya perempuanlah yang dibebani dengan kewajiban tersebut dalam situasi sang suami tidak mampu untuk memberikan nafkah. Kenyataan ini berkorelasi dengan kepemimpinan dalam rumah tangga yang dalam tafsir-tafsir klasik, secara umum dikaitkan dengan kelebihan lakilaki -salah satunya adalah karena nafkah -sehingga laki-lakilah yang berhak untuk menjadi pemimpin. Berbeda dengan Ibn Hazm yang menyebut kepemimpinan dalam rumah tangga bersifat kondisional, artinya dimungkinkan seorang perempuan menjadi pemimpin selama memiliki kapasitas yang mendukungnya.

\section{Daftar Pustaka}

Abu Ayd, Arif Khalil Muhammad. Al-Imam Dawud al-Dzahiri Wa Atsaruhu Fi al-Fiqh al-Islami. Kuwait: Dar al-Arqam, 1984.

Al-Khadimi, Nuruddin. Al-Dalil 'Ind al-Dzahiriyah. Damaskus: Dar Ibn Hazm, 2000.

Al-Andalusi, Abu Muhammad Ali Ibn Ahmad Ibn Sa'id Ibn Hazm. Al-Muhalla Bi alAtsar. Vol. 8. Beirut: Dar al-Kutub Ilmiyah, 2003.

Abu Muhammad Ali Ibn Ahmad Ibn Sa'id Ibn Hazm. Al-Muhalla Bi alAtsar. Vol. 9. Beirut: Dar al-Kutub Ilmiyah, 2003. . Al-Nubadz Fi Ushul al-Fiqh al-Dzahiri. Beirut: Dar Ibn Hazm, n.d. . Ibthal Al-Qiyas Wa al-Ra'y Wa al-Istihsan Wa al-Taqlid Wa al-Ta'lil. Damaskus: Matba'ah Jami'ah Damaskus, 1960.

perempuan dalam lingkup domestik maupun privat. Faqihuddin Abdul Qadir, Qira'ah Mubadalah: Tafsir Progresif untuk Keadilan Gender dalam Islam (Yogyakarta: IRCiSoD, 2019), 60.

57 M. Fauzan Zenrif, Tafsir Fenomenologi Kritis: Interrelasi Fungsional antara Teks dan Realitas (Malang: UIN Maliki Press, 2012), 96. 
Maratib al-Ijma' fi al-'Ibadat wa al-Mu'amalat wa al-I'tiqadat. Beirut: Dar Ibn Hazm, 1998.

Al-Bukhari, Muhammad Ibn Isma'il. Shahih Al-Bukhari. Vol. 5. Damaskus: Dar Ibn Katsir, 1996.

Al-Alusi, Mahmud, Ruh al-Ma'ani fi Tafsir al-Quran al-Adzim wa Sab'u al-Matsani, Vol. 3. Beirut: Dar al-Fikr, 2001.

Al-Naja, 'Imaduddin Abu, Matn al-Arba'in al-'Imadiyah fi al-Huquq al-Zawjiyah. Mesir: t.tp.: t.th.

Al-Samara'i, Abdul Hamid Husain. "Ta'tsir al-Wad' al-Siyasi Ala al-Madzhab alDzahiri." Majallah Al-Jamiah Tigris Li al-Ulum al-Insaniyah 16, no. 2 (2009).

Al-Syuwa'ir, Abdussalam Ibn Muhammad, Atsar 'Amal al-Mar'ah fi al-Nafaqat alZawjiyah. Riyad: Jami’ah al-Imam Muhammad Ibn Sa’ud al-Islamiyah, 2011.

Al-Qurtubi, Abu Abdillah Muhammad Ibn Abi Bakr, al-Jami' li Ahkam al-Quran, Vol. 4. Beirut: Muassasah al-Risalah, 2006.

Ash-Shiddieqy, Hasbi. Pokok-Pokok Pegangan Imam-Imam Madzhab dalam Membina Hukum Islam. Jakarta: Bulan Bintang, 1974.

Asmawi. Fiqh Zahiriyah: Metode Penggalian Hukum Islam Dalam Perspektif Historis Sosiologis. Tulungagung: STAIN Tulungagung Press, 2011.

. "Rasionalisasi Tradisi Bermazhab Menurut Shah Wali Allah." Epistemé:

Jurnal Pengembangan Ilmu Keislaman 8, no. 1 (June 4, 2013). https://doi.org/10.21274/epis.2013.8.1.29-52.

_. Studi Hukum Islam: Dari Tekstualis-Rasionalis sampai Rekonsiliatif. Yogyakarta: Teras, 2012.

Fierro, Maribel. "Why Ibn Hazm Became a Zāhirī: Charisma, Law and the Court: Published in Hamsa. Journal of Judaic and Islamic Studies 4 (2017-March 2018), 1-21 Hamawy, Yaqut al-. Mu'jam al- 'Udaba.' Kairo: Dar al-Ma'mun, n.d.

Hadi, Abdul, "Istinbat Hukum Islam Perspektif Az-Zahiri”, NURANI, 14, no. 2 (2014).

Hasbillah, Ahmad 'Ubaydi. "Nalar Tekstual Ahli Hadis Dalam Ormas Modernis Dan Tradisionalis Islam Di Indonesia." UIN Syarif Hidayatullah, 2017.

Himayah, Mahmud 'Ali, Ibn Hazm wa Manhajuh fi Dirasat al-Adyan. t.tp.: Dar alMa'arif, 1983.

Khoirin, Nur "Penalaran Ushul Fiqh Ibnu Hazm (Analisis Penolakan 'Illat dan Qiyas sebagai Dalil Hukum Islam", Yudisia: Jurnal Pemikiran Hukum dan Hukum Islam 9, no. 1 (2018).

Mutahhari, Murtadha, Nidzam Huquq al-Mar'ah fi al-Islam. Iran: Dzawi al-Qurba, 2005.

Muslim, Abu al-Husain Muslim Ibn Hajjaj Ibn, Shahih Muslim. Riyad: Dar al-Salam, 2000.

Nawawi, Muhammad Ibn 'Umar, Mirah Labid li Kasyf Ma'na Qur'an al-Majid, Vol. 1. Beirut: Dar al-Kutub al-'Ilmiyah, 1997.

ibn Rusyd, Muhammad Ibn Ahmad Ibn Muhammad, Bidayat al-Mujtahid wa Nihayat al-Muqtashid, Vol. 3. Kairo: Maktabah Ibn Taymiyah, 2001. 
62 | De Jure: Jurnal Hukum dan Syari’ah, Vol. 11 No. 1 Tahun 2019

'Itr, Nuruddin. Dawud Al-Asbahani Wa Haqiqat al-Madzhab al-Dzahiri. Nasyim alSyam, n.d.

Qadir, Faqihuddin Abdul, Qira'ah Mubadalah: Tafsir Progresif untuk Keadilan Gender dalam Islam. Yogyakarta: IRCiSoD, 2019.

Shu'aylayk, Muhammad Abdullah Abu. Al-Imam Ibn Hazm al-Dzahiri: Imam Ahl alAndalus. Damaskus: Dar al-Qalam, 1995.

Syaibah, 'Abdul Qadir. Itsbat Al-Qiyas Fi al-Syari'ah al-Islamiyah Wa al-Radd 'ala Munkirih. Riyadh, 1996.

Thahir, A. Halil. "Metode Ijtihad Menurut Ibnu Hazm: Telaah Kitab al-Ihkām Fi Ușūl al-Ahkām." Realita: Jurnal Penelitian Dan Kebudayaan Islam 14, no. 2 (November 9, 2016). https://doi.org/10.30762/realita.v14i2.241.

Tsaqafi, Muhammad Ibn Syadid Ibn Syidad, Ilzamat Ibn Hazm al-Dzahiri li al-Fuqaha' min Khilal Kitabih al-Muhalla: Dirasah wa Taqwim”, Disertasi. Makkah: Jami'ah Umm al-Qura, 2011.

'Uweis, Abdul Halim. Ibn Hazm Al-Andalusia Wa Juhuduh Fi al-Bahth al-Tarikhiy Wa al-Hadariy. Kairo: Al-Zahra li al-I'lam al-Arabi, 1988.

Wartini, Atik. "Jaminan Sosial Dalam Pandangan Ibnu Hazm Dan Relevansinya Dengan Pengembangan Jaminan Sosial Di Indonesia." HUNAFA: Jurnal Studia Islamika 11, no. 2 (2014): 245-75. https://doi.org/10.24239/jsi.v11i2.356.245275.

Wirman, Hardi Putra. "Problematika Pendekatan Analogi (Qiyas) Dalam Penetapan Hukum Islam (Telaah atas Pemikiran Ibn Hazm dan Ibn Qayyim al-Jawziyah)." . 47, no. 1 (January 1, 2013). https://doi.org/10.14421/asy-syir'ah.2013.\%x.

Zacharias, Diana. "Fundamentals of the Sunnī Schools of Law." Heidelberg Journal of International Law 66 (2006).

Zahrah, Muhammad Abu. Tarikh Al-Madzahib al-Islamiyah Fi al-Siyasah Wa al-Aqa'id Wa Tarikh al-Madzahib al-Fiqhiyyah. Kairo: Dar al-Fikr al-Arabi, n.d.

Zenrif, M. Fauzan, Tafsir Fenomenologi Kritis: Interrelasi Fungsional antara Teks dan Realitas. Malang: UIN Maliki Press, 2012. 